\title{
Synthesis of $\mathrm{K}_{2} \mathrm{Ti}_{4} \mathrm{O}_{9}$ by the Hydrolysis of $\mathrm{KOH}-\mathrm{Ti}\left(\text { iso }-\mathrm{C}_{3} \mathrm{H}_{7} \mathrm{O}\right)_{4}$ Ethanol Solution
}

\author{
Yoshihito SAKURAI and Tetsuro YOSHIDA \\ Department of Chemistry, Faculty of Science and Engineering, Meisei University, Hodokubo, Hino-shi, Tokyo 191
}
$\mathrm{KOH}$ と $\mathrm{Ti}$ (iso- $\left.\mathrm{C}_{3} \mathrm{H}_{7} \mathrm{O}\right)_{4}$ 混合エタノール溶液の加水分解による 四チタン酸カリウムの合成

櫻井良仁・吉田哲郎

明星大学理工学部化学科, 191東京都日野市程久保2-1-1

[Received June 30, 1990; Accepted October 26, 1990]

\begin{abstract}
The precipitates with $\mathrm{TiO}_{2} / \mathrm{K}_{2} \mathrm{O}$ molar ratio $=4$ were obtained by hydroysis of $\mathrm{KOH}-\mathrm{Ti}\left(\text { iso- } \mathrm{C}_{3} \mathrm{H}_{7} \mathrm{O}\right)_{4}$ ethanol solution. The dried product was amorphous, and changed to a crystalline intermediate by heat-treating at about $600^{\circ} \mathrm{C}$. The well grown submicron crystals of $\mathrm{K}_{2} \mathrm{Ti}_{4} \mathrm{O}_{9}$ were obtained by heat-treatment at $1000^{\circ} \mathrm{C}$ for $1 \mathrm{~h}$.
\end{abstract}

Key-words: Hydrolysis precipitates, Amorphous, Crystalline intermediate, Heat-treatment, $\mathrm{K}_{2} \mathrm{Ti}_{4} \mathrm{O}_{9}$ crystals, Cation-exchanger

\section{Introduction}

The crystals of potassium tetratitanate $\mathrm{K}_{2} \mathrm{Ti}_{4} \mathrm{O}_{9}{ }^{1), 2)}$ have layer structure, and it is possible from them to obtain the hydrogen tetratitanate hydrate $\left(\mathrm{H}_{2} \mathrm{Ti}_{4} \mathrm{O}_{9}\right.$. $n \mathrm{H}_{2} \mathrm{O}$ ) by the acid treatment. These hydrated crystals are noticed to be useful for cation exchangers. In the case of melting method, $\mathrm{K}_{2} \mathrm{Ti}_{4} \mathrm{O}_{9}$ is formed by the peritectic reaction of $\mathrm{K}_{2} \mathrm{Ti}_{6} \mathrm{O}_{13}$ and melt during cooling. 3) This reaction proceeds slowly if the molten oxides of stoichiometric composition is cooled from high temperature and so the crystals of single phase are difficult to be obtained. It is also difficult to obtain well grown crystals by sintering the dry mixtures.

The experimental results were reported in the previous paper. ${ }^{3)}$ The mixed ethanol solution of metal alkoxides was hydrolyzed, and the amorphous precipitates were heat-treated at the temperature lower than the peritectic temperature and the well grown crystals of single phase $\mathrm{K}_{2} \mathrm{Ti}_{4} \mathrm{O}_{9}$ were obtained.

In this paper, the synthesis of $\mathrm{K}_{2} \mathrm{Ti}_{4} \mathrm{O}_{9}$ crystals was carried out by using the more stable and useful reagent $\mathrm{KOH}$ in place of potassium alkoxides. One of the hydrolysis products, $\mathrm{KOH}$, is known to be dissolved about $29 \mathrm{wt} \%$ in $\mathrm{C}_{2} \mathrm{H}_{5} \mathrm{OH}$ at $28^{\circ} \mathrm{C}$. However, it reacted with the hydrolysis product of titanium isopropoxide directly and the precipitates which were insoluble in the water-ethanol solution were obtained. The dried precipitates were amorphous. However, the well grown submicrometer-sized crystals of $\mathrm{K}_{2} \mathrm{Ti}_{4} \mathrm{O}_{9}$ single phase was found to be ob- tained by heat-treating the dried precipitates.

\section{Experimentals}

All chemicals used were of reagent grade and without any purification. Ethanol was treated by molecular sieve for $24 \mathrm{~h}$ for dehydration, and $10 \% \mathrm{KOH}$ ethanol solution was prepared. The apparatus for hydrolysis was as same as in the previous paper. ${ }^{3)}$ However, the $\mathrm{pH}$ values of filtrates were measured after the dilution of filtrates to $1 / 100$ to eliminate the obstruction of ethanol and by using the glass electrode $\mathrm{pH}$ meter $\mathrm{HM}-7 \mathrm{E}$ together with HM-20S (Toa Electronics Ltd.) in this paper.

The synthetic procedure of $\mathrm{K}_{2} \mathrm{Ti}_{4} \mathrm{O}_{9}$ is as follows. $\mathrm{Ti}$ (iso- $\left.\mathrm{C}_{3} \mathrm{H}_{7} \mathrm{O}\right)_{4}$ was added to (1) $10 \mathrm{wt} \%\left(\mathrm{CH}_{3}\right)_{3}$ $\mathrm{COK}$ ethanol solution or (2) $10 \mathrm{wt} \% \mathrm{KOH}$ ethanol solution and the mixed ethanol solutions were obtained. They were hydrolyzed by adding waterethanol solutions (water content 9.5-63 wt\%). The hydrolysis reactions were carried out at $72^{\circ}-75^{\circ} \mathrm{C}$ for $1 \mathrm{~h}$ by stirring and refluxing. The hydrolysis products were sealed in Teflon container and reserved in water bath at $30^{\circ} \mathrm{C}$ for $24 \mathrm{~h}$ for aging. The amounts of $\mathrm{KOH}$ unreacted and remained in the filtrates were estimated by the measurements of their $\mathrm{pH}$ values. The precipitates were dried at $100^{\circ} \mathrm{C}$ for $24 \mathrm{~h}$. The dried precipitates were heattreated at various temoeratures. The heat-treated samples were analyzed by X-ray diffruction (XRD) to identify crystalline phases and morphological observation was carried out by scanning electron microscopy (SEM).

\section{Results and discussion}

3.1 The hydrolysis conditions and products

The hydrolysis reaction of the mixed alkoxides in ethanol solution is

$$
\begin{aligned}
& 2\left(\mathrm{CH}_{3}\right)_{3} \mathrm{COK}+4 \mathrm{Ti}\left(\text { iso }-\mathrm{C}_{3} \mathrm{H}_{7} \mathrm{O}\right)_{4}+18 \mathrm{H}_{2} \mathrm{O} \\
& =2 \mathrm{KOH}+4 \mathrm{Ti}(\mathrm{OH})_{4}+2\left(\mathrm{CH}_{3}\right)_{3} \mathrm{COH} \\
& +16 \text { iso- } \mathrm{C}_{3} \mathrm{H}_{7} \mathrm{OH}
\end{aligned}
$$

Then the dehydration and crystallization reaction take place by drying and heat-treating.

$$
2 \mathrm{KOH}+4 \mathrm{Ti}(\mathrm{OH})_{4}=\mathrm{K}_{2} \mathrm{Ti}_{4} \mathrm{O}_{9}+9 \mathrm{H}_{2} \mathrm{O}
$$


Therefore totally

$$
\begin{aligned}
& 2\left(\mathrm{CH}_{3}\right)_{3} \mathrm{COK}+4 \mathrm{Ti}\left(\text { iso- } \mathrm{C}_{3} \mathrm{H}_{7} \mathrm{O}\right)_{4}+9 \mathrm{H}_{2} \mathrm{O} \\
& =\mathrm{K}_{2} \mathrm{Ti}_{4} \mathrm{O}_{9}+2\left(\mathrm{CH}_{3}\right)_{3} \mathrm{COH}+16 \text { iso- } \mathrm{C}_{3} \mathrm{H}_{7} \mathrm{OH}
\end{aligned}
$$

and

$$
\begin{aligned}
& 2 \mathrm{KOH}+4 \mathrm{Ti}\left(\text { iso }-\mathrm{C}_{3} \mathrm{H}_{7} \mathrm{O}\right)_{4}+7 \mathrm{H}_{2} \mathrm{O} \\
& =\mathrm{K}_{2} \mathrm{Ti}_{4} \mathrm{O}_{9}+16 \text { iso- } \mathrm{C}_{3} \mathrm{H}_{7} \mathrm{OH}
\end{aligned}
$$

when $\mathrm{KOH}$ is used.

From Eq. (1) the molar ratio of K-tert-butoxide: Tiisopropoxide: $\mathrm{H}_{2} \mathrm{O}$ is $1: 2: 4.5$ in formular weight. On the other hand from Eq. (2) KOH: Ti-isopropoxide: $\mathrm{H}_{2} \mathrm{O}$ is $1: 2: 3.5$.

The amounts of $\mathrm{KOH}$ unreacted and remained in filtrate after the hydrolysis were compared in the case of using $\mathrm{KOH}$ with $\mathrm{K}$-alkoxide $\left(\left(\mathrm{CH}_{3}\right)_{3} \mathrm{COK}\right)$ by the experiments No. 1-5 in Table 1 . The hydrolysis conditions such as the reaction temperature $\left(72^{\circ}-\right.$ $\left.75^{\circ} \mathrm{C}\right)$, the total ethanol quantity $\left(\left[\mathrm{C}_{3} \mathrm{H}_{5} \mathrm{OH}\right] /\left[\mathrm{K}_{2} \mathrm{O}\right]\right.$ $=48$ ), the aging time (1day) and temperature $\left(30^{\circ} \mathrm{C}\right)$ were selected to be same. The $\mathrm{pH}$ values of the filtrates in sample No. 1-5 were less than or nearly equal to 7 . The $\mathrm{pH}$ values of less than 7 were considered to be equilibrated ones by absorbing $\mathrm{CO}_{2}$ in the atmosphere during the measurements. The ion exchanged pure water used for the dilution of the filtrates at the $\mathrm{pH}$ measurement showed also nearly the same value of $\mathrm{pH}$. Therefore $\mathrm{KOH}$ quantities in these filtrates were considered to be negligible small from their $\mathrm{pH}$ values. These results were nearly the same when the water content was increased from molar ratio $\mathrm{H}_{2} \mathrm{O} / \mathrm{K}_{2} \mathrm{O}=7.0$ to 74 . $\mathrm{KOH}$ reacted with the hydrolysis product of titanium isopropoxide, and the precipitates which $\mathrm{TiO}_{2} / \mathrm{K}_{2} \mathrm{O}$ molar ratio $=4$ were obtained.

\subsection{Change of hydrolysis product by heat-treat- ment and crystal growth}

The XRD pattern of the sample No. 1-5 showed nearly the same change when heat-treated at various temperatures. The typical XRD pattern of the samples prepared by using $\mathrm{KOH}$ was shown in Fig. 1 . The only halo with maximum at about $d=0.3$ $\mathrm{nm}\left(2 \boldsymbol{\theta}=29^{\circ}\right)$ caused by amorphous structure was observed in the samples which were dried at $100^{\circ} \mathrm{C}$ for 24 th and heat-treated at $400^{\circ} \mathrm{C}$ for $1 \mathrm{~h}$. The crystalline diffraction lines began to appear in the sample heat-treated at $600^{\circ} \mathrm{C}$. These lines are different from those of $\mathrm{K}_{2} \mathrm{Ti}_{4} \mathrm{O}_{9}$ (mark $)$ and unknown. This

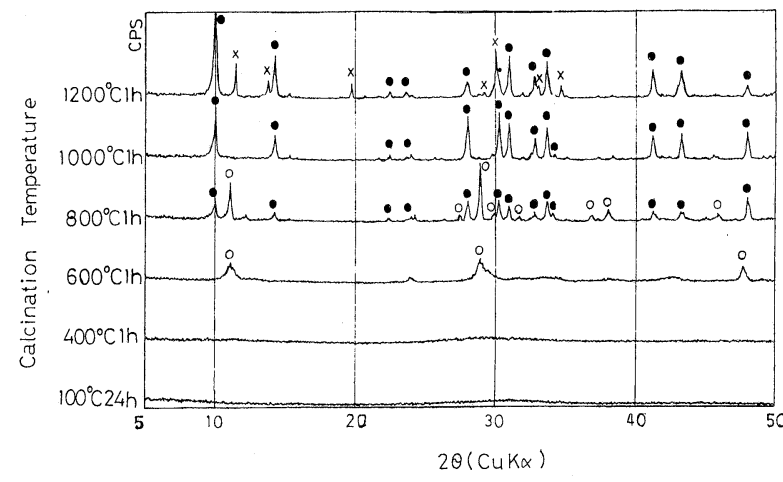

Fig. 1. XRD pattern of sample No. 2 using $\mathrm{KOH}$ after heat-treated at various temperatures.

$\bigcirc$ : intermediate, $\mathrm{O}: \mathrm{K}_{2} \mathrm{Ti}_{4} \mathrm{O}_{9}, \times: \mathrm{K}_{2} \mathrm{Ti}_{6} \mathrm{O}_{13}$

unknown crystalline phase disappears when the crystals of $\mathrm{K}_{2} \mathrm{Ti}_{4} \mathrm{O}_{9}$ is formed by heat-treating at the higher temperature. Therefore, these diffraction lines are considered to be those of intermediate crystals (mark $\bigcirc$ ). Exothermic peak corresponding to this crystallization was observed at $560^{\circ}-580^{\circ} \mathrm{C}$ in DTA of sample No. 1-5. The mixed phases of intermediate and $\mathrm{K}_{2} \mathrm{Ti}_{4} \mathrm{O}_{9}$ crystals were observed when heat-treated at $800^{\circ} \mathrm{C}$ for $1 \mathrm{~h}$. The only sharp diffraction lines of $\mathrm{K}_{2} \mathrm{Ti}_{4} \mathrm{O}_{9}$ crystals were observed in the sample heat-treated at $1000^{\circ} \mathrm{C}$ for $1 \mathrm{~h}$ and their intensities were much increased. Therefore the samples heat-treated at $1000^{\circ} \mathrm{C}$ are confirmed to be well grow $\mathrm{K}_{2} \mathrm{Ti}_{4} \mathrm{O}_{9}$ crystals. In the sample heat-treated at $1200^{\circ} \mathrm{C}$ for $1 \mathrm{~h}$, the deposition of $\mathrm{K}_{2} \mathrm{Ti}_{6} \mathrm{O}_{13}(\operatorname{mark} \times)$ was observed which was caused by the incongruent melting of $\mathrm{K}_{2} \mathrm{Ti}_{4} \mathrm{O}_{9}$ by the peritectic reaction $\mathrm{K}_{2} \mathrm{Ti}_{4}$ $\mathrm{O}_{9} \rightarrow \mathrm{K}_{2} \mathrm{Ti}_{6} \mathrm{O}_{13}+$ melt at $1114^{\circ} \mathrm{C} . \mathrm{K}_{2} \mathrm{Ti}_{4} \mathrm{O}_{9}$ was identified by Dion et al.'s results ${ }^{4)}$ as shown in Table 2. The good agreement is obtained except weak diffraction lines $2.999(\AA)$ and $2.749(\AA)$ which are confirmed to belong to no diffraction lines possible other than $\mathrm{K}_{2} \mathrm{Ti}_{4} \mathrm{O}_{9}$. The reason is now under investigation.

Figure 2 shows the SEM photographs of sample No. 2 which were dried at $100^{\circ} \mathrm{C}$ for $24 \mathrm{~h}$ and heattreated at $600^{\circ} \mathrm{C}, 800^{\circ}$ and $1000^{\circ} \mathrm{C}$ for $1 \mathrm{~h}$ respectively. The dried precipitates were amorphous and ag-

\begin{tabular}{|c|c|c|c|c|c|c|c|c|}
\hline \multirow{2}{*}{$\begin{array}{r}\text { Sample } \\
\text { No. }\end{array}$} & \multirow{2}{*}{$\begin{array}{l}\text { Starting } \\
\text { Material }\end{array}$} & \multicolumn{2}{|c|}{ Hydrolysis } & \multirow{2}{*}{$\begin{array}{c}{\left[\mathrm{TiO}_{2}\right] /\left[\mathrm{K}_{2} \mathrm{O}\right]} \\
\text { mole } \\
\text { ratio }\end{array}$} & \multirow{2}{*}{$\begin{array}{c}{\left[\mathrm{H}_{2} \mathrm{O}\right] /\left[\mathrm{K}_{2} \mathrm{O}\right]} \\
\text { mole } \\
\text { ratio } \\
(\mathrm{a}),\end{array}$} & \multirow{2}{*}{$\begin{array}{c}{\left[\mathrm{C}_{2} \mathrm{H}_{5} \mathrm{OH}\right] /\left[\mathrm{K}_{2} \mathrm{O}\right]} \\
\text { mole } \\
\text { ratio }\end{array}$} & \multirow{2}{*}{$\begin{array}{c}\text { Filtrate } \\
\text { pH }\end{array}$} & \multirow{2}{*}{$\begin{array}{l}\text { Crystalline } \\
\text { phase. } \\
\text { after calcined } \\
\text { at } 1000^{\circ} \mathrm{C}, 1 \mathrm{~h}\end{array}$} \\
\hline & & $\begin{array}{l}\text { Reaction } \\
\left(\text { temp } /{ }^{\circ} \mathrm{C} \text { ) }\right.\end{array}$ & $\begin{array}{l}\text { Aging } \\
\text { (time/d) }\end{array}$ & & & & & \\
\hline 1 & $\left(\mathrm{CH}_{3}\right)_{3} \mathrm{COK}$ & $72-75$ & 1 & 4.0 & $9.0(1.0)$ & 48 & 6.8 & $\mathrm{~T}$ \\
\hline 2 & $\mathrm{KOH}$ & $72-75$ & 1 & 4.0 & $7.0(1.0)$ & 48 & 6.3 & $\mathrm{~T}$ \\
\hline 3 & $\left(\mathrm{CH}_{3}\right)_{3} \mathrm{COK}$ & $72-75$ & 1 & 4.0 & $18(2.0)$ & 48 & 6.6 & $\mathrm{~T}$ \\
\hline 4 & $\mathrm{KOH}$ & $72-75$ & 1 & 4.0 & $28(4.0)$ & 48 & 6.6 & $\mathrm{~T}$ \\
\hline 5 & $\mathrm{KOH}$ & $72-75$ & 1 & 4.0 & $74(11)$ & 48 & 6.7 & $\mathrm{~T}$ \\
\hline
\end{tabular}
gregated as shown in Fig. 2(a). The small angle scattering was observed in the XRD pattern of this sam-

Table 1. The conditions of hydrolysis and the identified crystalline phases after calcination. 
Table 2. XRD analysis of sample prepared by this method.

\begin{tabular}{|c|c|c|c|c|}
\hline \multicolumn{3}{|c|}{$\begin{array}{c}\mathrm{K}_{2} \mathrm{Ti}_{4} \mathrm{O}_{9} \text {, Dion et al } \\
\text { (1.981) JCPDS32-861 }\end{array}$} & \multicolumn{2}{|c|}{$\begin{array}{l}\text { sample No.2 } \\
\left(1000^{\circ} \mathrm{C}, 1 \mathrm{~h}\right)\end{array}$} \\
\hline$d(A)$ & $I / I_{1}$ & hkl & $d(A)$ & $I / I_{1}$ \\
\hline 8.76 & 100 & 200 & 8.803 & 100 \\
\hline 6.19 & 35 & 201 & 6.197 & 48 \\
\hline 5.75 & 2 & 002 & $-\cdots$ & -- \\
\hline 4.09 & 1 & $40 \overline{2}$ & $\ldots$ & - \\
\hline 3.95 & 3 & $20 \overline{3}$ & 3.962 & 12 \\
\hline 3.75 & 3 & 401 & 3.751 & 8 \\
\hline 3.71 & 2 & 110 & 3.707 & 13 \\
\hline 3.18 & 35 & 310 & 3.181 & 87 \\
\hline \multirow[t]{2}{*}{3.08} & $<1$ & 402 & - & -- \\
\hline & & & 2.999 & 11 \\
\hline 2.95 & 35 & 311. & 2.953 & 97 \\
\hline 2.88 & 30 & 004 & 2.884 & 78 \\
\hline \multirow[t]{2}{*}{2.80} & 1 & $40 \overline{4}$ & ----- & -- \\
\hline & & & 2.749 & 13 \\
\hline 2.72 & 20 & $603 \bar{~}$ & 2.728 & 43 \\
\hline 2.66 & 30 & $31 \overline{3}$ & 2.658 & 71 \\
\hline 2.62 & 4 & 312 & 2.618 & 12 \\
\hline 2.55 & $<1$ & $51 \overline{2}$ & 2.555 & 7 \\
\hline 2.344 & 3 & $11 \overline{4}$ & 2.344 & 8 \\
\hline 2.270 & $<1$ & $80 \bar{I}$ & $-\cdots$ & - \\
\hline 2.186 & 25 & 512 & 2.188 & 56 \\
\hline 2.089 & 25 & 205 & 2.089 & 55 \\
\hline 2.047 & 2 & $71 \overline{3}$ & ---- & - \\
\hline 1.986 & 2 & 314 & 1.987 & 10 \\
\hline 1.895 & 10 & 020 & 1.895 & 59 \\
\hline 1.854 & 2 & 220 & 1.852 & 7 \\
\hline 1. 838 & 1 & 405 & 1.837 & 7 \\
\hline 1.827 & 2 & 712 & 1.824 & 9 \\
\hline 1.752 & 2 & $91 \overline{3}$ & 1.752 & 13 \\
\hline 1.744 & 8 & $11 \bar{\sigma}$ & 1.742 & 20 \\
\hline
\end{tabular}

ple. However, the scattering disappeared when heattreated at $400^{\circ} \mathrm{C}$ for $1 \mathrm{~h}$. Its SEM image was observed to be nearly same as shown in Fig. 2 (a). By heat-treating at $600^{\circ} \mathrm{C}$ for $1 \mathrm{~h}$ the dried precipitates were changed to the crystalline intermediates which were investigated by the XRD analysis as shown in Fig. 1 and rather amorphous than crystalline in shape (Fig. 2(b)). They were changed to the mixture of pillar-like and plate-like crystals in shape when heat-treated at $800^{\circ} \mathrm{C}$ for $1 \mathrm{~h}$ (Fig. $2(\mathrm{c})$ ). The samples heat-treated at $1000^{\circ} \mathrm{C}$ for $1 \mathrm{~h}$ were well grown pillar-like crystals of length from about 600 to $800 \mathrm{~nm}$ which were confirmed to be $\mathrm{K}_{2} \mathrm{Ti}_{4} \mathrm{O}_{9}$ crystals by the XRD analysis and the plate-like crystals disappeared (Fig. 2(d)).

\section{Conclusion}

The synthesis of $\mathrm{K}_{2} \mathrm{Ti}_{4} \mathrm{O}_{9}$ crystals was investigated by hydrolyzing the mixed $\mathrm{KOH}$ and $\mathrm{Ti}$ (iso- $\mathrm{C}_{3} \mathrm{H}_{7}$ O) ${ }_{4}$ ethanol solution and heat-treating hydrolysis product.

The results are as follows;

(1) All hydrolysis products were amorphous which were insoluble in the water-ethanol solutions when $\mathrm{TiO}_{2} / \mathrm{K}_{2} \mathrm{O}$ molar ratio $=4.0$.
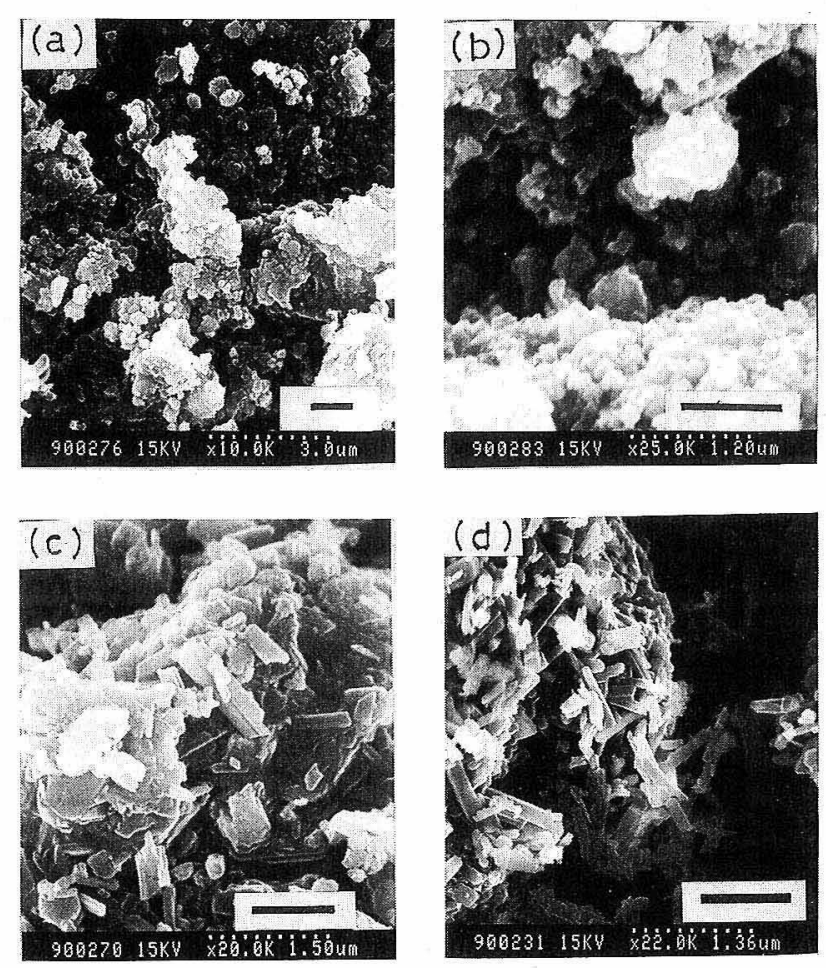

Fig. 2. SEM photographs of the sample No. 2 heat-treated at various temperatures

(a) $100^{\circ} \mathrm{C}, 24 \mathrm{~h}$; (b) $600^{\circ} \mathrm{C}, 1 \mathrm{~h}$; (c) $800^{\circ} \mathrm{C}, 1 \mathrm{~h}$; (d) $1000^{\circ} \mathrm{C}, 1 \mathrm{~h}$; (bar $=1 \mu \mathrm{m}$ )

(2) The dried precipitates heat-treated at $600^{\circ} \mathrm{C}$ for $1 \mathrm{~h}$ were changed from amorphous to unknown intermediate crystals.

(3) The intermediate crystals were changed to well-grown $\mathrm{K}_{2} \mathrm{Ti}_{4} \mathrm{O}_{9}$ crystals by heat-treating them at $1000^{\circ} \mathrm{C}$ for $1 \mathrm{~h}$.

(4) No difference between of starting material $\left(\mathrm{CH}_{3}\right)_{3} \mathrm{COK}$ and $\mathrm{KOH}$ was found from the above results. Therefore, it was confirmed that the synthesis of $\mathrm{K}_{2} \mathrm{Ti}_{4} \mathrm{O}_{9}$ crystals was possible by using $\mathrm{KOH}$ as well as $\mathrm{K}$-alkoxide.

Acknowledgements The authors are greatly indebted to the high-temperature chemical laboratory of Keio University for obtaining thermal analysis data. They also thank Professor Ryuji Satoh of Meisei University for his encouragement.

\section{References}

1) H. Izawa, S. Kikkawa and M. Koizumi, J. Phys. Chem., 86, 5023-26 (1982).

2) Y. Fujiki, Y. Komatsu and T. Sasaki, Hyomen, 24, 683-91 (1986)

3) Y. Sakurai and T. Yoshida, Nippon Kagaku Kaishi, 1989, 33-38.

4) M. Dion, Y, Piffard and M. Tournoux, J. Inorg. Nucl. Chem., 40, 917-18 (1978), (JCPDS 32-861). 